\title{
En embolus, flere emboli - eller?
}

\author{
Svært mange leger bruker ordet «emboli» feil. Men det er kanskje ikke så rart.
}

I en oversiktsartikkel i Tidsskriftet fra noen år tilbake kan man lese at «Det er beregnet at opp til $30 \%$ av alle hjerneslag hos pasienter med atrieflimmer har annen årsak enn embolier fra hjertet» (1). For den språkinteresserte pedant vil dette kanskje skurre litt. I flere ordbøker står det nemlig at emboli er flertallsform av embolus (som for øvrig vil si en partikkel i blodbanen) (2-5). Det korrekte er altså å bøye en embolus til flere emboli, og ikke til flere embolier, som gjort ovenfor. Tenker man seg litt om, er det jo egentlig ganske selvsagt - vi bøyer for eksempel sulcus til sulci uten å tenke noe videre over det, selv om å dette til og med innebærer et skifte av konsonant når vi uttaler det. Likevel, forfatterne av den nevnte setningen er så definitivt ikke alene. Snarere synes riktig bruk, som her eksemplifisert ved en setning fra en annen artikkel i Tidsskriftet, å være unntaket heller enn regelen: «Forekomsten av spontane cerebrale emboli ble målt ved én times undersøkelse med transkranial doppler» (6).

\section{Årsaken til feilbruken}

Hvordan kan det ha seg at vi omgir oss med så omfattende feilbruk av dette forholdsvis enkle substantivet? Svaret er kanskje at vi har gjort det litt vanskelig for oss selv. I tillegg til at emboli, som så ettertrykkelig poengtert, er flertallsformen av embolus, er som kjent også emboli innarbeidet som synonym til embolisme, det vil si selve tilstoppingen av blodkaret, som når vi snakker om sykdommen lungeemboli. I dette tilfellet fungerer faktisk emboli som entallsform, og flertallsformen blir dermed embolier.

Disse to betydningene av ordet emboli sammenblandes ofte, og mange bruker følgelig samme ord uansett om det er en embolus eller en emboli(sme) det er snakk om.

\section{Viktig å skille \\ mellom propp og propping}

Når det ovenfor slås fast hva som er riktig bruk av disse ordene, vil nok de noe eldre, trofaste leserne av denne spalten påpeke at det faktisk ikke stemmer helt. Som sagt oppgir riktignok flere ordbøker bøyingen en embolus, flere emboli. Tanums store rettskrivningsordbok, derimot, som er gjennomgått av Språkrådet, har i mange år gått inn for å bøye en embolus til flere emboluser. Denne bøyingen virker således å være den offisielle, og synes hensiktsmessig da man blant annet unngår samme ord $\mathrm{i}$ bestemt

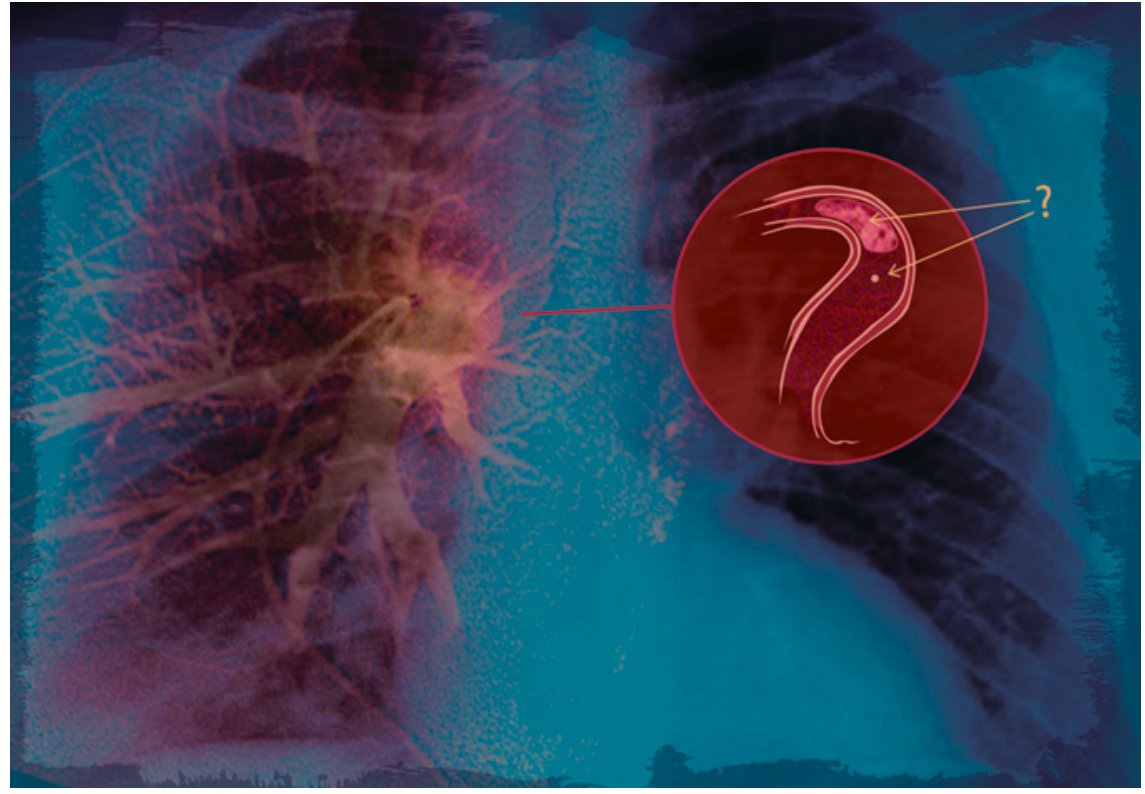

Illustrasjon @ Stein Løken

form flertall (emboliene) av de to ofte sammenblandede begrepene. Imidlertid kan bøyingen oppfattes som unaturlig. Uavhengig av hvilken bøying man foretrekker i dette noe intrikate landskapet, vil det viktigste uansett være å skille mellom embolus og emboli(sme), i den hensikt å unngå mulige misforståelser.

\section{Håkon Kravdal}

hakon_kravdal@hotmail.com

Oslo

Håkon Kravdal (f. 1988) begynner som turnuslege ved Harstad sykehus høsten 2013.

\section{Litteratur}

1. Berge E, Dahl T. Hjertesykdom og hjerneslag. Tidsskr Nor Lægeforen 2007: 127: 897-9.

2. Øyri A, Øyri B. Norsk medisinsk ordbok. 8. utg Oslo: Samlaget, 2007.

3. Nylenna M. Medisinsk ordbok. 7. utg. Oslo: Kunnskapsforlaget, 2009.

4. Berulfsen B, Gundersen D. Fremmedord og synonymer blå ordbok. Oslo: Kunnskapsforlaget, 2005

5. Lindskog BI. Gyldendals store medisinske ordbok. 2. utg. Oslo: Gyldendal Akademisk, 2003.

6. Frich JC. Skyldes demens cerebrale mikroemboli? Tidsskr Nor Lægeforen 2006; 126: 1589.

Mottatt 5.4. 2013 og godkjent 19.4. 2013. Medisinsk redaktør Raida Ødegaard.

\section{Redaksjonen svarer:}

Håkon Kravdal tar opp et gammelt, men likevel aktuelt spørsmål. Han grunngir også godt årsaken til forvirrende praksis. Det har vært og er fremdeles en vaklende bruk av ordene embolus og emboli(sme), og det er forskjellige meninger om bøyningen av dem.

Problemstillingen ble mye diskutert i Språkspalten i begynnelsen av 1990årene. Det ble der påpekt at formen emboli ble ukritisk brukt om både propp og propping, at ordet embolus ble lite brukt og at resultatet dermed ble svekket presisjonsnivå (1). Sammenfallet mellom entallsformen emboli (propping) og flertallsformen emboli (propper) kunne avhjelpes ved at embolus fikk norsk flertallsendelse: emboluser, embolusene (2). Det ville være i tråd med at ord med latinsk opprinnelse i økende grad har fått norske endelser, f.eks. uterus, uteruser. I Tidsskriftet nr. 27/1993 var det fire innlegg i diskusjonen. Det var uenighet om å benytte flertallsformen emboluser, men større enighet om å benytte formen embolisme for emboli og slik løse problemet med sammenfallende former (3-6). Utfallet ble et forslag om å benytte flertallsformen emboluser istedenfor emboli og formen embolisme for emboli (7). (På den måten ville formen emboli bli 